International Journal of Learning, Teaching and Educational Research

Vol. 20, No. 8, pp. 50-67, August 2021

https://doi.org/10.26803/ijlter.20.8.4

Received May 27, 2021; Revised Aug 15, 2021; Accepted Aug 30, 2021

\title{
Effect of the Use of WebQuest in a Chinese for Tourism Course at a Thai University: An Exploratory Study
}

\author{
Pairin Srisinthon \\ Walailak University, Nakhon Si Thammarat, Thailand \\ https://orcid.org/0000-0003-3693-3163
}

\begin{abstract}
In trying to move away from teacher-centred approaches towards student-centred approaches amidst the global Covid-19 pandemic, integrating technology into foreign-language classes has been considered. Under these conditions, this study implemented WebQuest technology in a Chinese for Tourism class, followed by adopting a mixed-methods research approach to investigate the student learning. This study aimed to 1) assess the learning achievement of 63 students as part of a Chinese for Tourism course using WebQuest to provide the instructional materials alongside the face-to-face format, and 2) to collect the learners' opinion on the WebQuestbased activities. SPSS was used for the quantitative analysis and thematic analysis was used to analyse the interview data. The development of the WebQuest lessons began with a critical and analytical review of the existing literature related to the WebQuest course design. The WebQuest lessons were then implemented for six weeks after which the students' learning achievements were evaluated. The findings revealed that after using WebQuest, the learners' Chinese language ability test scores were higher than before utilizing the instrument. The students were satisfied with the WebQuest lessons with varying satisfaction levels for the questionnaire items. The benefits of teaching and learning in connection to the WebQuest lessons got the highest score. From the 15 learners' semi-structured interviews, it was found that the majority of the learners agreed that teaching and learning through the WebQuest lessons was a modern method offering convenient access due to the lack of time limitations.
\end{abstract}

Keywords: tourism WebQuest; Chinese majoring students; Chinese teaching; Chinese language; mixed methods

(C)Author

This work is licensed under a Creative Commons Attribution-NonCommercial-NoDerivatives 4.0 International License (CC BY-NC-ND 4.0). 


\section{Introduction}

According to the statistics of the Thai Tourism Department, approximately 8.8 million Chinese travelled to Thailand in 2016. This number is higher than the number of ASEAN (Association of Southeast Asian Nations) tourists travelling to Thailand. The need to use Chinese in the tourism industry is high. Based on the reports from the Centre of Cooperative Education and Career Development of Walailak University (2016-2018), most students majoring in Chinese chose to do their work-integrated learning in companies related to the tourism industry such as hotels, airports, and tour companies. Many of Thailand's universities offer Chinese for Tourism courses to support the growth of the tourism industry.

The Chinese major curricula try to meet the requirements of the tourist industry by offering students Chinese for Tourism courses to prepare them for real-world careers. Chinese for Tourism is a Chinese for Specific Purposes course dealing with specific Chinese vocabulary and expressions in the field in the areas of business, travel, and an introduction to tourist attractions (Traveling Chinese Glossary Program Group, Foreign Chinese College, Shanghai Normal University, 2008). This course assists the students in improving their Chinese language skills when it comes to travel and tourism. The Chinese for Specific Purposes course involves the teaching and learning of Chinese as a second or foreign language of which the aim is the ability to use Chinese in their career activities. Teaching and learning Chinese for specific purposes requires a methodology that differs entirely or partially from the one used when teaching for the purpose of language skills (Traveling Chinese Glossary Program Group, Foreign Chinese College, Shanghai Normal University, 2008). The instructors of such a course face the challenges of structure, technical vocabulary and field-specific knowledge (Zheng, 2018). They also encounter the challenge of a paradigm shift from the teachercentred approach to the student-centred approach (Wang, 2021; Zheng, 2018). It is important to determine the teaching processes that suit the changing world and the newer generations of students (Chen, 2018). The designers of this course must integrate the expected Chinese language skills with the intended content knowledge to support the learners' needs (Baker, 2018). In order to move away from the teachercentred approach to concentrate on the student-centred approach, most educators suggest that teachers integrate technology into the Chinese language class. Since technology plays an important role in society today, how to take advantage of technology as part of supporting Chinese teaching is an issue worth studying.

Under these conditions, WebQuest technology is an effective tool with which to engage the learners throughout the process of learning (Kaur and Kauts, 2018). In the context of teaching and learning Chinese in Thailand, a few detailed studies were conducted on the utilization of WebQuest in the Chinese classroom. Meanwhile, due to the many years of experience in teaching the Chinese language, the researchers found that the students were rarely actively involved when it came to finding educational information on the Internet. The level of knowledge seeking from the Chinese Internet network is very low. The management of the Chinese for Tourism course was made more effective by connecting to both Thai and Chinese networks,

http://ijlter.org/index.php/ijlter 
allowing the learners to practise their language skills and learn more effectively through interactions with their teachers and peers. This study attempted to find a way to enhance the level of student learning. Exploring how WebQuest can be best used will benefit many groups of people, be they course designers, course lecturers, or students.

\section{Literature Review and Theoretical Frameworks}

Given the technological advancements in recent years, conducting research on the application of technology in teaching that had been done over the past ten years, and integrating online technology into the learning process were found to have a positive influence on the students' learning engagement (Dunlap \& Lowenthal, 2018; Bognar, Sablic \& Skugor, 2019). In order to improve the teaching methods and classroom environment, many educational institutions use new technology (e.g., tech-based learning) as part of their language classrooms (Berezova, Mudra \& Yakushko, 2018; Dousti, Amirian \& Nejadansari, 2021). Technology has the potential to offer quite a number of free learning materials online for learning activities (Teng, 2017; Gao, Shen \& Wang, 2020). Given the advancements in technology and the ways in which the new generation of students learn (Martin \& Bolliger, 2018), education institutions need to provide access to web-based teaching and stimulate the learners to utilize Internet resources as part of the learning process. Learning through authentic materials from the Internet offers an active classroom environment as part of a learner-centred activity and a level of communication among the instructors, learners, and their peers. The differences between tech-based learning and traditional learning are compared in Table 1 (see Wasim, Sharma \& Siddiqui, 2014, p. 448).

Table 1: Comparison of Tech-based Learning and Traditional Learning

\begin{tabular}{|l|l|}
\hline \multicolumn{1}{|c|}{ Tech-based learning } & \multicolumn{1}{c|}{ Traditional Learning } \\
\hline Student-centred instruction & Teacher-centred instruction \\
Multi-sensory stimulation & Single-sense stimulation \\
Multi-path progression & Single-path progression \\
Multimedia & Single media \\
Collaborative work & Isolated work \\
Information exchange & Information delivery \\
Active/exploratory/inquiry-based learning & Passive learning \\
Critical thinking and informed decision- & Factual, knowledge-based learning \\
making & Isolated, artificial context \\
Authentic, real-world context & \\
\hline
\end{tabular}

Based on Table 1, WebQuest is more ideal for teaching and learning as it offers what the students should experience, for example, student-centred instruction, collaborative work, inquiry-based learning, active learning and critical thinking (Ebadi \& Rahimi, 2018), which is a more suitable approach to learning for the current world of working.

http://ijlter.org/index.php/ijlter 


\subsection{What is WebQuest?}

Web-based lessons (WebQuest) are designed based on the tech-based learning model created by Professor Bernie Dodge and Tom March of San Diego State University as a learning tool to gain information from the Internet or long-distance networks. It offers access to online resources under the supervision of the instructor (Sakadineca \& Jansone, 2018). The learners utilize appropriate and relevant content which the instructors provide to complete their learning tasks. Dodge (2001:?:) describes WebQuest as "an inquiry-oriented activity in which some or all of the information that learners interact with comes from resources on the Internet". March (2003) also notes that WebQuest is an effective instrument with links to web resources and tasks that encourage the students to find the answers to the open-ended questions to develop their personal expertise and group collaboration skills in order to transfer new information, leading to deeper learning.

According to Kazakova and Klyoster (2018) and Kaur and Kauts (2018) two forms of WebQuest exist, namely (i) short-term WebQuest, which provides one to three lessons, focused on the learning and application of specific skills, and (ii) long-term WebQuest which takes as long as three weeks to approximately one month to master. The learners will analyse the new knowledge in a classroom setting with their peers and will learn to apply it to real-life situations.

Based on the tech-based learning model, WebQuest includes five parts, namely an introduction, a task, process, evaluation and conclusion (Millsion \& Downey, 2001; Sakadineca \& Jansone, 2018; Zendler \& Klein, 2018; Berezova et al., 2018). These warrant a brief description:

a. Introduction: Briefly explains the information and activities, and tries to stimulate the students to solve the problems.

b. Task: Clearly explains the tasks and important results that the students must find.

c. Process: Clarifies what activities the students must perform in order to achieve their tasks, and provides information sources available on the Internet and other resources, in order for the students to use appropriate sources to solve their assigned problems, focusing on multiple sources of knowledge and diversity.

d. Evaluation: Focuses on the criteria for assessing the learning tasks.

e. Conclusion: Summarizes the main objectives and experiences of the students during the learning process.

Several studies have been conducted using the WebQuest approach (Kazakova \& Kloyster, 2018; Ebadi \& Rahimi, 2018; Sakadineca \& Jansone, 2018; Chen, 2019; Adanan, Adanan \& Herawan, 2020). These studies have shown that the WebQuest process supports the learners' level of learning engagement and the level of enjoyment of their studies. WebQuest also enhances the learners' critical thinking skills by tasking them with analysing information and completing tasks. For example, Sakadineca and Jansone (2018) designed WebQuest tasks for the purpose of teaching the Latvian language and literature. The results showed that all the students in the 
class positively worked in groups and were active when it came to using WebQuest to complete their tasks. Liang and Fung (2020) implemented WebQuest in an English classroom to stimulate the students' critical thinking skills. Their findings revealed that after implementing the WebQuest-based critical thinking programme, the students' thinking skills improved, especially in terms of their vocabulary when expressing their opinions. Similarly, Wang (2021) used WebQuest for the purpose of supporting the students to actively participate in the information technology (IT) classroom. They found that the students engaged with their learning more and that their problem-solving abilities increased.

Researchers claim that the WebQuest technology, as an interactive method, can be successfully implemented in the field of teaching foreign languages. They believe that after the implementation of WebQuest and other learning methods such as collaborative projects, problem-based classrooms or flipped classrooms in the field of language acquisition, the learners' language competency performance will be significantly improved (Awada \& Dihab, 2018; Berezova et al., 2018; Adanan et al., 2020; Synekop, 2020). Awada and Dihab (2018) investigated student's academic writing performance after integrating Student Team Achievement Division (STAD) and WebQuest into their learning process. The results of the study showed that these web-based interventions improved the students' academic writing performance. Furthermore, all the teacher participants developed more positive perceptions of web-based instruction. Teng (2017) introduced the concept of a flipped classroom, by dividing three EFL (English Foreign Language) classes into a structured flipped classroom, a semi-structured flipped classroom, and a traditional classroom. It was found that using WebQuest in the flipped classroom was a most effective way to increase the learners' academic performance in the pre-post test score comparison. Zheng (2018) supported using WebQuest as a teaching and learning tool in the Chinese classroom. He conducted a comparative study of two classes. The experimental group was a trial group that used online lessons, while the control group used lecture-based teaching. The instructor designed the course content according to Hanban's "International Chinese Language Course Layout" and provided the video clips about the Chinese content and culture from the Internet. The web lessons were also designed to provide sufficient interactivity between the learners and the lecturer through an online group chat. At the end of the semester, the learners took an HSK test (Chinese Proficiency Test for assessing non-native Chinese speakers' Chinese skills). It was found that the HSK scores of the learners who followed lectures through the web were significantly higher than those of the learners in the control group. The results gathered from the questionnaires indicated that most of the learners from the web-learning group were satisfied with the selfcontrolled learning process. They also strongly agreed to watching video clips in small groups. The study proved that WebQuest encourages learners to learn, analyse, synthesize and provide solutions that have been discovered by themselves or in small groups. In addition, the group that learned Chinese online were confident when learning with Chinese students. On the contrary, the students who studied in the control group were not confident when studying with Chinese students in their own 
majors. This is because they did not understand the lectures given by the Chinese instructors. A similar study by Chen (2018) showed that patients with hearing problems who studied Chinese pronunciation through online classes got higher scores after having used web lessons. They progressed in their listening performance and were able to discuss interactions with a medical professional about their hearing problems. The web lessons made it easier for the learners to communicate effectively.

The integration of WebQuest in classrooms provides learners with the ability to gather information from various websites. This can help the learners to understand both the linguistic and cultural aspects, and to improve their intercultural competence (Awada and Diab, 2018; Kazakova \& Klyoster, 2018; Ebadi \& Rahimi, 2018). Awada and Diab (2018) divided EFL learners from eight different countries into experimental and control groups. They provided the experimental group with the Inquiry-based Intercultural Communication Technological Model. The control group received regular instructions. The findings show that the participants in the experimental group had a strong intrinsic motivation towards conducting culturally based debates in a setting that ensured intercultural communication.

Learning through WebQuest allows learners to learn without time limitations. The students have to be self-directed, active and autonomous when it comes to searching for information before referring to the instructor who acts as the facilitator. This solves the problem of over-dependence on the instructors to deliver knowledge and to identify problems (Synekop, 2020). It has been proven that the students improved their self-esteem and self-confidence by taking part in a more participative course.

The reviewed studies show that most of the studies discussed, were conducted on the use of WebQuest in EFL classrooms. Further studies are recommended to investigate the use and outcomes of WebQuest technology in other subjects. More studies, therefore, will be required to determine the effects of the WebQuest approach on Chinese teaching. This will help us to understand the advantages of this technology in a holistic manner.

\section{Study Objectives}

This study aimed to investigate the effectiveness of WebQuest technology when implemented in a Chinese for Tourism class. The research questions were as follows:

1. What were the learners' achievements after the Chinese for Tourism course through WebQuest?

2. What were the learners' opinions about the WebQuest lessons?

\section{Research Methodology}

\subsection{Research design}

The mixed-methods design was used to explore the learners' achievements and their opinion of learning via the WebQuest lessons. The independent variable was the implemented WebQuest lessons which included the Chinese for Tourism course 
content. The dependent variables included the learners' achievements and their opinion of the WebQuest instruction. The first dependent variable was measured by comparing the pre-test and post-test scores. The second dependent variable was measured using the post-instruction questionnaires and informal group interviews. The quantitative data from the questionnaires and the pre-post-test scores were analysed using SPSS and an analysis of variance (ANOVA) respectively. The qualitative data from the informal group interviews were analysed using thematic analysis.

\subsection{Research site and participants}

This research was conducted at a university in southern Thailand. The university emphasizes teaching; all of the teaching staff had passed the UK-based Advanced HE Training Programme (the active teaching and learning programme used for training university instructors provided by the Higher Education Academy). On this basis, its lecturers emphasize their teaching, paying close attention to the learning of individual students, adopting formative assessments and feedback, and focusing on analytical and critical thinking. Moreover, the university encourages its instructors to teach using active-based methods and to employ empirical research. The participants in this study were 63 undergraduate Thai students majoring in Chinese who were enrolled in the Chinese for Tourism course offered in the first term of the 2019 academic year. This course was selected because its objective was the use of Chinese in their professional activities or areas of specialization. The students attended five 50-minute class periods per week in a smart classroom where each student was allowed to use his/her personal computer or mobile phone. Fifteen interviewees were selected using the volunteering system.

\subsection{Research instruments}

The instruments used in this study included WebQuest for the Chinese for Tourism Class, the pre-test and post-test, and the post-instruction questionnaire. The learners' Chinese proficiency and the learning objectives were considered before WebQuest was created specifically for the course. The course was offered to third-year Chinese majors who had studied approximately 1,000 words for everyday use. The WebQuest lessons consisted of six steps: 1) Introduction; 2) Task; 3) Process; 4) Resources; 5) Evaluation, and 6) Conclusion (Dodge, 2001). The WebQuest lessons were divided into two main parts, one for the administrator or instructor and one for the learners. The WebQuest lessons covered communication contexts that the learners could genuinely apply elsewhere. The contents consisted of Ticket Booking, Welcome to Thailand, Check-in Procedures, Room Reservation, and Checking in and Checking out at a hotel. WebQuest on Chinese for Tourism was provided to the participants for the purpose of learning in the classroom and outside of it. It consisted of Chinese content on tourism, online exercises, links to useful internal and external websites, and communication suggestions via e-mail and Facebook.

The performance test consisted of the pre-test and post-test developed from the course content. This was used to evaluate the learners' proficiency regarding their Chinese for Tourism knowledge and their Chinese language proficiency before and 
after studying the course using the WebQuest lessons. Similarly, the pre-test and post-test consisted of ten multiple-choice questions, twenty gap-filling items, ten true-false questions and five sentences to write using the words provided. The total score for the performance test was 50 points.

The post-instruction questionnaire was developed by the researcher after conducting a literature review on the effectiveness of WebQuest in supporting the learning process. It was used to measure the learners' attitude towards the use of web resources for learning as part of the Chinese for Tourism Course and it was administered at the end of said course. The questionnaire was divided into three main aspects: the WebQuest Design, the WebQuest Lesson Content, and the Usefulness of WebQuest. It used a Likert scale for the items ranging from 1 (not at all satisfied) to 5 (extremely satisfied). Three invited Item Objective Congruence IOC experts validated the questionnaire. The score obtained was over 0.67 .

Subsequent to the questionnaire response session, fifteen learners from the class attended the semi-structured interviews on a voluntary basis. Each interviewee had approximately ten minutes to respond to a set of open-ended questions. Notes were taken by the interviewer and a research assistant, in order to record the key ideas as part of the data analysis. All proper interview protocols were adhered to at all times, including confidentiality.

\subsection{Data collection and data analysis}

The quantitative data were collected using a questionnaire and the qualitative data were gathered using semi-structured interviews. The Statistical Package for the Social Sciences software (SPSS) was used for the data analysis. The data collected were analysed using the mean, standard deviation and $t$-test. Analysis of variance (ANOVA) was conducted to compare the pre-test and post-test score differences with a significance level of 0.05 . The questionnaire items were interpreted using the included Likert scale ranges based on Best's criteria (Best, 1986).

$1.00-1.80=$ Not at all satisfied

$1.81-2.60=$ Slightly satisfied

$2.61-3.40=$ Moderately satisfied

$3.41-4.20=$ Very Satisfied

$4.21-5.00=$ Extremely satisfied

Thematic analysis was used to analyse the data from the interviews (see Braun \& Clarke, 2019; Terry \& Hayfield, 2021). The interview data were identified and coded. Five major themes emerged from the data.

4.5 Research procedure

The research procedure is depicted in the following table (Table 2):

http://ijlter.org/index.php/ijlter 
Table 2: Research procedure

\begin{tabular}{|c|l|l|l|}
\hline Item & \multicolumn{1}{|c|}{ Research Procedure } & \multicolumn{1}{|c|}{ Purpose } & \multicolumn{1}{c|}{ Timeline } \\
\hline 1 & $\begin{array}{l}\text { Designing the WebQuest } \\
\text { lessons, performance tests } \\
\text { and opinion questionnaire }\end{array}$ & $\begin{array}{l}\text {-To prepare the learning } \\
\text { materials and research } \\
\text { instruments }\end{array}$ & $\begin{array}{l}\text { Before } \\
\text { conducting the } \\
\text { research }\end{array}$ \\
\hline 2 & $\begin{array}{l}\text { Evaluating the students' } \\
\text { Chinese proficiency using } \\
\text { the pre-test }\end{array}$ & $\begin{array}{l}\text {-To measure the learners' } \\
\text { background knowledge of } \\
\text { Chinese for Tourism. }\end{array}$ & $\begin{array}{l}\text { Before the } \\
\text { experiment }\end{array}$ \\
\hline 3 & $\begin{array}{l}\text { Implementing WebQuest } \\
\text { for Chinese for Tourism }\end{array}$ & $\begin{array}{l}\text {-To introduce how to use the } \\
\text { WebQuest lessons, learning } \\
\text { tasks, and objective goals. } \\
\text {-To provide the specific } \\
\text { Chinese skills needed in the } \\
\text { tourism industry, focusing on } \\
\text { the specific vocabularies } \\
\text { around accommodation, travel } \\
\text { methods, sightseeing and } \\
\text { holidays. }\end{array}$ & weeks \\
\hline 4 & $\begin{array}{l}\text { Evaluating the student } \\
\text { learning using the post-test }\end{array}$ & $\begin{array}{l}\text {-To evaluate their learning } \\
\text { achievements }\end{array}$ & $7^{\text {th }}$ week \\
\hline 5 & $\begin{array}{l}\text { Collection of the data } \\
\text { through a questionnaire }\end{array}$ & $\begin{array}{l}\text {-To measure the students' } \\
\text { opinions of/on the WebQuest } \\
\text { lessons }\end{array}$ & $8^{\text {th } \text { week }}$ \\
\hline 6 & $\begin{array}{l}\text { Collection of the data } \\
\text { through interviews }\end{array}$ & $\begin{array}{l}\text {-To gain more information } \\
\text { about the effectiveness of the } \\
\text { WebQuest lessons }\end{array}$ & 8 - 9th week \\
\hline
\end{tabular}

\subsection{Ethical considerations}

Before beginning the experiment, the details of the purpose and methodology of the research were explained to the participants for them to feel respected and appreciated after they had left the project. All the participants were requested to return a copy of their completed consent form before conducting the research. They could withdraw from the study at any time. The researcher treated the information gathered from the individuals confidentially without disclosing the participants' identity. In addition, all the data gathered from the participants were only available to the researcher and were kept in a secure location.

\section{Results}

\subsection{Learners' academic achievements}

The first research question aimed to determine the learners' level of achievement after studying the Chinese for Tourism course through WebQuest. Table 3 depicts a comparison of the students' pre-test and posttest scores. 
Table 3: Comparison of the learners' pre-test and post-test scores

\begin{tabular}{|ll|c|c|c|c|c|}
\hline & Mean & $\mathrm{N}$ & Std. Deviation & Std. Error Mean & Sig. \\
\hline Pair 1 & Pre-test & 7.30 & 63 & 4.01 & 0.52 & .000 \\
& Post-test & 21.30 & 63 & 6.22 & 0.81 & \\
\hline
\end{tabular}

The statistics for academic performance in Table 3 indicate that the learners' achievements were positive with higher scores after studying the Chinese for Tourism course through the WebQuest lessons at a significance level of 0.000 (Sig. < 0.005).

\subsection{Learners' opinions}

The second research question was answered by the questionnaire and the interview data, the findings of which are shown in the following table.

Table 4: Learners' opinions about the WebQuest lessons

\begin{tabular}{|c|l|c|c|l|}
\hline Item & \multicolumn{1}{|c|}{ Aspect } & Mean & S.D. & Level of Satisfaction \\
\hline 1 & $\begin{array}{l}\text { Diverse formats of information } \\
\text { and content presentation }\end{array}$ & 3.00 & 0.53 & Moderately satisfied \\
\hline 2 & Interesting presentation & 2.95 & 0.66 & Moderately satisfied \\
\hline 3 & Creative design & 3.47 & 2.57 & Very satisfied \\
\hline 4 & The font used & 3.26 & 0.72 & Moderately satisfied \\
\hline 5 & Web colours & 3.38 & 0.72 & Moderately satisfied \\
\hline 6 & Linked tabs & 3.01 & 0.65 & Moderately satisfied \\
\hline 7 & $\begin{array}{l}\text { Easy to communicate between the } \\
\text { learners and the instructors }\end{array}$ & 3.03 & 0.73 & Moderately satisfied \\
\hline 8 & Easy access to other resources & 3.00 & 0.71 & Moderately satisfied \\
\hline 9 & Appropriate tasks and evaluations & 3.14 & 0.64 & Moderately satisfied \\
\hline 10 & Online feedback of the learners & 2.84 & 0.65 & Moderately satisfied \\
\hline The overall average value & $\mathbf{3 . 1 1}$ & $\mathbf{0 . 6 5}$ & Moderately satisfied \\
\hline
\end{tabular}

Table 4 shows that the overall average value of the learners' satisfaction with the WebQuest design was 3.11. When considering the individual aspects, the highest mean score was for Item 3 (mean=3.47). This means that the learners seemed to be quite satisfied with the design of WebQuest even though they had never used web-based lessons before. Because of the technical problems, the aspect of online feedback got the lowest mean score. 
Table 5: Learners' Opinions about the WebQuest Lesson Content

\begin{tabular}{|c|l|c|c|l|}
\hline Item & \multicolumn{1}{|c|}{ Aspect } & Mean & S.D. & $\begin{array}{c}\text { Level of } \\
\text { Satisfaction }\end{array}$ \\
\hline 1 & Web structure & 3.92 & 0.58 & Very satisfied \\
\hline 2 & $\begin{array}{l}\text { Suitable content according to the } \\
\text { learning objective }\end{array}$ & 3.85 & 0.65 & Very satisfied \\
\hline 3 & $\begin{array}{l}\text { Modern application of the } \\
\text { content }\end{array}$ & 4.20 & 0.71 & Very satisfied \\
\hline 4 & $\begin{array}{l}\text { Genuine application of the } \\
\text { content }\end{array}$ & 4.25 & 0.71 & Extremely satisfied \\
\hline 5 & $\begin{array}{l}\text { Language and content accuracy } \\
\text { and reliability }\end{array}$ & 4.06 & 0.64 & Very satisfied \\
\hline 6 & Enough resources to use & 3.73 & 0.75 & Very satisfied \\
\hline The overall average value & $\mathbf{4 . 0 0}$ & $\mathbf{0 . 6 8}$ & Very satisfied \\
\hline
\end{tabular}

According to Table 5, it can be concluded that the learners were highly satisfied with the content of the WebQuest lessons. They were satisfied with the authentic application of the content as indicated by giving it the highest mean score (mean = 4.25). The reason behind this might simply be that the learners are much more concerned about utilizing their Chinese for Tourism knowledge in real life. The learners also focused on the modern content that was beneficial for them to learn. The learners were highly satisfied with the accuracy and reliability of the language and content of the web lessons.

Table 6: Learners' Opinions of the usefulness of WebQuest

\begin{tabular}{|c|l|c|c|l|}
\hline Item & \multicolumn{1}{|c|}{ Aspect } & Mean & S.D. & Level of Satisfaction \\
\hline 1 & Provide self-study-based learning & 4.25 & 0.83 & Extremely satisfied \\
\hline 2 & $\begin{array}{l}\text { Enable the learners to learn anytime and } \\
\text { anywhere }\end{array}$ & 4.57 & 0.82 & Extremely satisfied \\
\hline 3 & Motivate the learners to study & 4.04 & 0.67 & Very satisfied \\
\hline 4 & Support the learners to solve problems better & 4.23 & 0.64 & Extremely satisfied \\
\hline 5 & $\begin{array}{l}\text { Develop the relationship among the } \\
\text { instructor, learners, and their peers }\end{array}$ & 4.15 & 0.55 & Very satisfied \\
\hline 6 & Develop their learning performance & 4.45 & 0.54 & Extremely satisfied \\
\hline 7 & Learners can control their learning process & 4.04 & 0.71 & Very satisfied \\
\hline 8 & Support critical thinking & 4.34 & 0.53 & Extremely satisfied \\
\hline 9 & $\begin{array}{l}\text { Gain knowledge that meets the learning } \\
\text { objective }\end{array}$ & 4.50 & 0.61 & Extremely satisfied \\
\hline 10 & $\begin{array}{l}\text { Appropriate tasks that meet the learning } \\
\text { objective }\end{array}$ & 4.54 & 0.65 & Extremely satisfied \\
\hline 11 & Discipline in learning & 3.73 & 0.88 & Very satisfied \\
\hline The overall average value & $\mathbf{4 . 2 5}$ & $\mathbf{0 . 6 8}$ & Extremely satisfied \\
\hline
\end{tabular}


As shown in Table 6, the learners were satisfied with the usefulness of the Chinese for Tourism WebQuest at a high level (mean $=4.25)$. The aspect of learning anytime and anywhere got the highest average score of 4.57. This indicates that the students were able to study without the limitations of time and space. The tasks provided by the Chinese for Tourism WebQuest were suitable for the learning objectives, thus the satisfaction of the learners was found to be at the highest level (mean $=4.54)$.

\subsection{Opinions on the WebQuest lessons from the interview data}

Based on the thematic analysis (Braun \& Clarke, 2019), the opinions of the students on the WebQuest lessons collected from fifteen interviewees were coded into the following categories:

Promoting autonomous learning

Supporting modern and up-to-date learning content

Practising technological skills

Enjoyed working in cooperative groups

Internet connectivity problems

Table 7: Learners' responses in each category

\begin{tabular}{|c|l|c|}
\hline Item & \multicolumn{1}{|c|}{ Category } & Total (person) \\
\hline 1 & Internet connectivity problems & 15 \\
\hline 2 & Supporting modern and up-to-date learning content & 15 \\
\hline 3 & Practising technological skills & 13 \\
\hline 4 & Enjoyed working in cooperative groups & 13 \\
\hline 5 & Promoting autonomous learning & 12 \\
\hline
\end{tabular}

Based on Table 7, all the interviewees found the Internet connectivity problem to be a big obstacle. However, the good points were that WebQuest supports modern and up-to-date learning content, that it gave them the opportunity to practise their technological skills, that they enjoyed working in cooperative groups and that it promoted autonomous learning.

\section{Promoting autonomous learning}

Twelve learners responded that integrating the WebQuest approach into the Chinese for Tourism Class was a new and modern learning method that enhanced their Chinese language skills development. They were able to learn anytime and anywhere after class. One interviewee said, "I spent a lot of time preparing for this course apart from classroom presentations. The assignments provided in the web helped me to better understand knowledge of Chinese for Tourism". Another interviewee added, "I preferred to depend on my own ability to search knowledge from Internet rather than following the teacher's guidance. My Chinese reading and translating skills also improved while working with Chinese posted articles". Only three learners said that they preferred not to participate in autonomous learning, and that they liked learning from the instructor's lectures.

http://ijlter.org/index.php/ijlter 
Supporting modern and up-to-date learning content

Studying through WebQuest encouraged the students to interact with new information from the web resources. As one commented, "The WebQuest contents are modern and useful, stimulate me to engage with learning". All interviewees commented that the information provided on WebQuest widened their knowledge of the course and that they could apply the information to real-life situations and in the workplace. Most of the interviewees reported that they saved time by getting the learning materials from the WebQuest lessons.

\section{Practising technological skills}

The students had no experience with the WebQuest instruction method prior to the course. Through WebQuest, they obtained technological skills and knowledge about the use of Internet-enhanced learning. Most of the interviewees noted that submitting the tasks online was easy and comfortable. Approximately $60 \%$ of the interviewees reported that the WebQuest Chinese for Tourism course had detailed and clear steps to help them carry out the learning tasks, presenting the tasks well and providing the related materials. They were able to practise more technological skills when completing their learning tasks.

\section{Enjoy working in cooperative groups}

Many of the learning tasks on WebQuest required being accomplished by cooperative groups. According to thirteen learners, they enjoyed working in cooperative groups to complete the assigned tasks. For example, one responded, "I was happy to work with my peers because we will help each other to complete the assigned tasks". Another interviewee responded, "I like to brainstorm with my classmates, this helped us to do the tasks better". Only two interviewees in the class reported that some of their peers were not responsible enough to do the tasks, meaning that they did not engage with their assigned cooperative groups.

\section{Internet connectivity problems}

Fifteen learners gave feedback on the technical problems including the weak wi-fi connection and the webpage not being stable. This problem interrupted the process of learning. Some of the students were worried about submitting the tasks late and getting no scores. Providing more explanations for selected vocabularies' meanings as part of the WebQuest lessons should be considered. Some of the students asked the instructor to explain the tasks provided on the webpage again in class.

\section{Discussion and Implications}

A number of studies focused on using WebQuest in English classrooms to develop the students' academic performance (Adanan et al., 2020; Baker, 2018; Kazakova \& Kloyster, 2018), but of these only a few studies (e.g., Zheng, 2018) have been conducted on implementing WebQuest in Chinese classrooms. This study attempted 
to find a way to improve the teaching and learning of Chinese using the principles of long-term WebQuest use (Dodge, 2001) to design web lessons for the Chinese for Tourism Course. The participants studied the web lessons for six weeks. The findings from this research indicate that learning through the Chinese for Tourism WebQuest resulted in higher scores in the learner's post-test compared to the pre-test scores at a significant level. This result agrees with the study by Zheng (2018) who revealed that the HSK (Chinese Proficiency Test) scores of the students taught through using web lessons were significantly higher. Overall, the investigation reflected the learners' positive satisfaction with the Chinese for Tourism WebQuest lessons at a high level. They enjoyed working with their peers to complete the learning tasks. These findings are compatible with the findings on using WebQuest to enhance English writing and reading performance, conducted by Berezova et al. (2018). They found that the students were actively engaged with the authentic and collaborative tasks provided through the Internet.

The students believed that the knowledge that they gained from practising Chinese for tourism through the web lessons could be applied in their daily life and in the workplace. Learning through web lessons is a new and modern style of Chinese learning. Through this mode of learning, the learners can improve their language skills. Dudeney (2003) points out that WebQuest technology is an effective tool to provide access to the Internet in a language classroom, and that it provides the learners with an opportunity to study with no time limits. Practising various tasks enabled the learners to understand the Chinese for Tourism content and to increase their knowledge of the vocabulary and expressions suitable for use in many situations when travelling. Similar results were reported by Awada and Diab (2018) and Liang and Fung (2020), namely that after implementation of the WebQuest in the EFL classrooms, the students' language competency improved.

This learning method fosters positive motivation and critical thinking. The results of this study confirm the inferences drawn from the previous studies that employing technological devices in the Chinese learning process enhances the learners' motivation and their enjoyment when studying (Seitkazy et al., 2016; Chen, 2019; Zheng, 2018, Wang, 2021). By learning through WebQuest lessons, the learners managed their own learning process with no time limitations (Mitsikopoulou, 2014; Liu, Huang \& Wosinski, 2017; Zeng \& Fu, 2019).

Although integrating the selected technology into the Chinese learning context in higher education contributed various advantages, problems did occur. The learners faced difficulties when trying to get connected to the Internet as they were fully dependent on the wi-fi connection provided by the university, both in the classrooms and in the dorms. A large number of users were utilizing the same access point at the same time, which was mostly at night. The Internet streaming became poor as a result, and sometimes the online connection was lost. As a multimedia programme, WebQuest lessons require a high storage capacity to run. This was the biggest problem when it came to the learners participating actively in the Chinese for

http://ijlter.org/index.php/ijlter 
Tourism WebQuest activities created by the instructor. Similar findings were also made in previous studies by Seitkazy et al. (2016), and Yarmakeev, Valiakhmetova, Akhmadullina and Terane (2019), who reported that the main problem with learning online was the weak Internet connection and poor condition of the computer equipment. This included that the mobile phone system was not effective enough to run the Chinese for Tourism WebQuest programme, thus preventing the learners from interacting. In this study, the instructors could not contact their students through WebQuest and they changed their method of contact to using Line or e-mail for the submission of assignments instead.

\section{Conclusion}

This research revealed that integrating the WebQuest lessons and technology into the Chinese learning process enhanced the development of Chinese regarding their tourism knowledge and Chinese language skills. The difference between the pre-test (7.30) and post-test scores (21.30) corroborates the learner's academic achievements. As for the questionnaire and interview results, the learners were positive regarding the use of WebQuest lessons to help them with the process of learning Chinese for tourism. According to the questionnaire responses, the learners were satisfied with the usefulness of WebQuest at a high level (mean $=4.25)$. The instructors should motivate and encourage the learners to utilize the Internet effectively by providing useful online resources related to the learning process. According to the interview data, the learners reported in their feedback on technical problems such as a weak wifi connection or WebQuest not being stable. The university should improve its Internet connection in order to encourage students to engage with the online learning environment. To solve the wi-fi connection problem, a WebQuest design allowing it to be used on both laptops and mobile phones should be considered.

\section{Acknowledgments}

This paper is part of the research study titled "The Innovation of Learning Chinese for Tourism by Using WebQuest", funded by the Innovation and Research Department of Walailak University, Thailand. This research and the informed consent were reviewed and approved by the Human Research Ethics Committee of Walailak University, based on the Declaration of Helsinki (Approval No. WUEC-19029-01).

\section{Recommendations}

It is recommended that more in-depth investigative studies and more research design types, such as experimental and control group research designs, be used to investigate technology-supported education on a wider scale. The scope should also be broadened concerning the examination of the students' achievements after learning through WebQuest. WebQuest should be implemented in other Chinese courses such as Business Chinese, Chinese Literature and Chinese Translation to gather more essential and useful information to fill the gaps in the literature for Chinese foreign language teaching that will benefit other Chinese language teachers and students.

http://ijlter.org/index.php/ijlter 


\section{References}

Adanan, H., Adanan, M., \& Herawan, T. (2020). M-WebQuest development: Reading comprehension of senior high school students in Indonesia. International Journal of Emerging Technologies in Learning (IJET), 15(3), 74-92. https://doi.org/10.3991/ijet.v15i03.10628

Awada, G., \& Diab, H. (2018). Effect of WebQuest media on learners' intercultural communication debate and motivation. 19 ${ }^{\text {th }}$ International CALL Conference (2018). Call Paper.

Baker, D. M. (2018). USA and Asia hospitality and tourism students' perceptions and satisfaction with online learning versus traditional face-to-face instruction. E-Journal of Business Education and Scholarship of Teaching, 12(2), 40-54. https://doi.org/10.33915/etd.2960

Berezova, L. M., Mudra, S. M., \& Yakushko, K. H. (2018). The effect of WebQuests on the writing and reading performance of university students. Information Technologies and Learning Tools, (64,2), 110-118. https:/ / doi.org/10.33407/itlt.v64i2.1979

Best, J. W. (1986). Research in Education 1986. Prentice-Hall.

Bognar, B., Sablić, M., \& Škugor, A. (2019). Flipped learning and online discussion in higher education teaching. Didactics of smart pedagogy (pp. 371-392). Springer, Cham. https://doi.org/10.1007/978-3-030-01551-0_19

Braun, V., \& Clarke, V. (2019). Reflecting on reflexive thematic analysis. Qualitative Research in Sport, Exercise and Health, 11(4), 589-597. https://doi.org/10.1080/2159676x.2019.1628806

Chen, J. (2019). Designing online project-based learning instruction for EFL learners: A WebQuest approach. MEXTESOL Journal, 43(2), 1-7.

Chen, X. (2018). Hearing rehabilitation training system based on Web. Beijing Biomedical Engineering. 37(1), 86-90.

Dodge, B. (1995). WebQuests: A technique for Internet-based learning. Distance Educator, 1(2), 10-13.

Dodge, B . (2001). Site overview:The WebQuests Page. http://webquest.sdsu.edu/overview.htm.

Dousti, M., Amirian, Z., \& Nejadansari, D. (2021). Application of WebQuest-based Instruction in Higher Education Context: EFL Students' Achievement in Writing Skill. Journal of English Language Teaching and Learning, 13(27), 113-136. https://doi.org/10.22034/elt.2021.42866.2312

Dudeney, G. (2003). The quest for practical web usage. Global Issues Special Interest Group. IATEFL ISSUES, 8-9.

Dunlap, J., \& Lowenthal, P. (2018). Online educators' recommendations for teaching online: $\begin{array}{lllll}\text { Crowd sourcing in } & \text { 79-89. }\end{array}$ https://doi.org/10.5944/openpraxis.10.1.721

Ebadi, S., \& Rahimi, M. (2018). An exploration into the impact of WebQuest-based classroom on EFL learners' critical thinking and academic writing skills: A mixed-methods study. Computer-Assisted Language Learning, 31(5), 617 651. https://doi.org/10.1080/09588221.2018.1449757 
Gao, H., Shen, H. D., \& Wang, Y. L. (2020). Diversified teaching mode reform of mechanical principle and design based on Internet plus. Life-Long Education, 9(5), 225. http://dx.doi.org/ 10.18282 /le.v9i5.1257

Hanban. (2004). Hanban's International Chinese Language Course Layout. Hanban Explained. https//everything.explained.today/Office_of_Chinese_Language_International/

Kaur, S., \& Kauts, A. (2018). Impact of WebQuest on student engagement. Indian Journal of Public Health Research \& Development, 9(12), 1665-1669. https:/ / doi.org/10.5958/09765506.2018.02230.1

Kazakova, O. P., \& Kloyster, A. M. (2018). Educational tasks modelled on the basis of the WebQuest technology (from the Experience of Teaching Foreign Languages). Astra Salvensis.

Liang, W., \& Fung, D. (2020). Development and evaluation of a WebQuest-based teaching programme: Students' use of exploratory talk to exercise critical thinking. International Journal of Educational Research, 104, 101652. https://doi.org/10.1016/j.ijer.2020.101652

Liu, D., Huang, R.., \& Wosinski, M. (2017). Smart learning in smart cities. Singapore: Springer Nature.

March, T. (2003). What WebQuests Are (Really). https://tommarch.com/writings/whatWebQuests-are/

Martin, F., \& Bolliger, D. U. (2018). Engagement matters: Student perceptions on the importance of engagement strategies in the online learning environment. Online Learning, 22(1), 205-222. https://doi.org/10.24059/olj.v22i1.1092

Millson, A. J., \& Downey, P. (2001). WebQuest: using Internet resources for cooperative inquiry. https://rc.library.uta.edu/utair/bitstream/handle/10106/11730/WebQuest\%20using\%20Internet\%2020resources .pdf?sequence $=1$

Mitsikopoulou, B. (2014). Introduction to Webquests. www.opencourses.uoa.gr/modules/docu

Sakadineca, O., \& Jansone, A. (2018). Students' attitudes toward learning activities organized with the means of WebQuest method. Baltic Journal of Modern Computing, 6(3), 271278. https://doi.org /10.22364/bjmc.2018.6.3.04

Seitkazy, P. B., Toleubekova, R. K., Amanova, A. K., Tashetov, A. A., Iskakova, G., \& Demissenova, S. S. (2016). A Web-Quest as a teaching and learning tool. International Electronic Journal of Mathematics Education, 11(10), 3537-3549.

Teng, M. F. (2017). Flipping the classroom and tertiary level EFL students' academic performance and satisfaction. Journal of Asia TEFL, 14(4), 605. https://doi.org/10.18823/asiatefl.2017.14.4.2.605

Synekop, O. (2020). WebQuest as technology of differentiated ESP instruction at university level. Journal of Teaching English for Specific and Academic Purposes,? 043-052. https:/ / doi.org/ 10.22190 /JTESAP2001043S

Terry, G., \& Hayfield, N. (2021). Conceptual foundations of thematic analysis. Essentials of thematic analysis, Number? Issue? pp. 3-14. American Psychological Association. https://doi.org/10.1037/0000238-001

Travelling Chinese Glossary Programme Group, Foreign Chinese College, Shanghai Normal University. (2008). Luyou Hanyu dagang [Outline of Traveling Chinese Function]. Shanghai Normal University.

http://ijlter.org/index.php/ijlter 
Walailak University. (2016-2018). Reports from the Centre of Cooperative Education and Career Development of Walailak University, Nakhon Si Thammarat Province, Thailand.

Wang, Y. H. (2021). Integrating modified WebQuest activities for programming learning. Journal of Computer Assisted Learning. https://doi.org/10.1111/jcal.12537

Wasim, J., Sharma, S. K., Khan, I. A., \& Siddiqui, J. (2014). Web-based learning. International Journal of Computer Science and Information Technologies, 5(1), 446-449.

Yarmakeev, I., Valiakhmetova N., Akhmadullina, R., \& Terane, G. (2019). WebQuest technologies as learning motivation. Helix. 9(5), 5307. 5310. https://doi.org/10.29042/2019-5307-5311

Zendler, A., \& Klein, K. (2018). The effect of direct instruction and WebQuest on learning outcomes in computer science education. Education and Information Technologies, 23(6), $2765-2782$.

Zeng, Q., \& Fu, J. (2019). Teaching mode of WebQuest in college English flip class under the mobile learning environment. Proceedings of $20195^{\text {th }}$ International Conference on Education Technology, Management and Humanities Science (ETMHS 2019). 11771181. http://doi.org/1025236/etmhs.2019.253

Zheng, Q. (2018). The teaching reform study based on Internet plus communicative task for elementary comprehensive course of TCFL. Jinhua Polytechnic Journal, 18(3), 21-27. 